\title{
Molecular characterization of growth hormone genes in Egyptian Tilapias
}

\author{
Mohsen. S. Hussein ${ }^{1}$; Mohamed. A. Rashed ${ }^{2}$; Mohamed. A. Ahmed ${ }^{1}$ and \\ Ahmed. M. Abd El-Tawab \\ 1- Department of Animal Production, Faculty of Agriculture, Al-Azhar University Cairo, \\ Egypt.
}

2- Department of Genetics, Faculty of Agriculture, Ain Shams University, Shubra ElKhema, Cairo, Egypt.

\section{ABSTRACT}

This study presented growth hormone $(\mathrm{GH})$ gene of three fish species in Egypt namely; Oreochromis niloticus (KT387598 accession number), Sarotherodon galilaeus (KT387599 accession number) and Tilapia zillii (KT387600 accession number) which belong to cichlids. The tilapiine species growth hormone (GH) genes were isolated and sequenced following amplification from genomic DNA by the polymerase chain reaction (PCR) technique. The sequences of $\mathrm{GH}$ gene were analyzed by GENEIOUS program ( V8.1) software. The gene lengths were variable among the three studied species which ranged from 1572bp to $1601 \mathrm{bp}$ and consisted of six exons and five introns. Was also described a novel polymorphism of the six exons and the five introns fragments. Exons showed 26 nucleotide polymorphisms (NPs) while the total number of NPs in introns was 37. A comparison between the three studied species indicated that $T$. zillii species was totally different from the others. It had three insertions and nine substitutions which were not existed in the other species. The sequencing predicted a polypeptide of 204 amino acids. The GH amino acid sequence of tilapiine species exhibited the homology in all amino acids expect only four amino acids which were different [Isoleucine (I) $>$ Threonine (T), Glycine $(\mathrm{G})>$ Arginine $(\mathrm{R})$, Leucine $(\mathrm{L})>$ Lysine $(\mathrm{K})$ and Leucine $(\mathrm{L})>$ Valine $(\mathrm{V})]$ in 78, 97, 132 and 133 sites, respectively; which all differences were only found in T. zillii species. In the phylogenetic tree the single outlier was T. zillii species.

Keywords: Characterization, Growth Hormone, Molecular, Egyptian Tilapias.

\section{INTRODUCTION}

Tilapia is a generic term used to designate a group of commercially important food fish belonging to the Cichlidae family; Cichlids are classified in the large order Perciformes, which consists of three aqua-cultural important genera; Oreochromis niloticus, Sarotherodon and Tilapia, which they inhabit in the fresh and brackish waters.

Tilapias have been introduced in many countries around the world. It has originated since more than 4000 years ago in Egypt. The first culture of tilapia was conducted in Kenya in at 1924. Of the 70 species of tilapias, only nine are used in farming and of these, only Nile tilapia (Oreochromis niloticus) is the main cultured species. These species is being farmed in about 85 countries worldwide (FAO, 2002). It grows to a maximum length of $62 \mathrm{~cm}$ (average size is $20 \mathrm{~cm}$ ), and weigh is $3.65 \mathrm{~kg}$ (at an estimated 9 years of age; Bwanika et al., 2004). Sarotherodon galilaeus growth range was about $16-34 \mathrm{~cm}$ in length and a maximum published weight was $1.6 \mathrm{~kg}$ (Stiassny et al., 2007). Meanwhile, Tilapia zillii grows up to 30 $\mathrm{cm}$ as a common length (max length is $40 \mathrm{~cm}$ ) (Van Oijen, 1995) and maximum published weight was $300 \mathrm{~g}$ (Kapetsky \& Petr, 1984). 
Growth hormone $(\mathrm{GH})$ has many important physiological roles in the control of growth, metabolism and reproduction (Glass, 2003, 2005; Ma et al., 2007; Velloso, 2008; Wood et al., 2005). It also called somatotropin (ST), which is synthesized and secreted by the somatotrope cells of the anterior pituitary gland (Agellon et al., 1988; Reinecke et al., 2005; Yowe \& Epping, 1995). In most species, GH consists of 191 amino acids and contains two disulphide bonds that maintain its three dimensional structure. The amino acid sequence of $\mathrm{GH}$ is similar to prolactin (PRL) and placental lactogen (PL). PRL, PL and GH have overlapping biological actions (Dänicke, 2006).The GH gene in various fish species has been extensively studied for potential applications with the target to enhance the growth rate of these species in aquaculture (Pendón et al., 1994).

The current study aimed to investigate the genetic aspects that contribute in controlling the growth trait through the sequencing of the GH gene among three Egyptian tilapias.

\section{MATERIALS AND METHODS}

\section{Materials}

Based on the most abundant tilapias in Borolus Lake, at Kafr El-Sheikh Governorate (Egypt), three tilapia species namely O. niloticus, S. galilaeus and T. zillii were collected in the current study.

\section{Methods}

\section{Growth hormone gene sequencing}

DNA was extracted from ten samples for eact per species according to Lopera-Barrero et al. (2008). Standard PCR reaction was performed using newly designed primers based on $O$. niloticus GH gene (GenBank accession M84774.1). Primers were designed to amplify the growth hormone gene in three sets of primer combinations to cover the CDS region including introns (Table 1).

Table 1: Primer combination sets, names, sequences $\left(5^{\prime} \rightarrow 3^{\prime}\right)$, expected $(\mathrm{bp})$ and melting temperature $(\mathrm{Tm})$ of the newly designed primers used in $\mathrm{GH}$ gene sequencing.

\begin{tabular}{|c|c|c|c|c|}
\hline Combination & Name & Sequence $\left(5^{\prime} \rightarrow 3^{\prime}\right)$ & $\mathbf{T m}$ & $\begin{array}{c}\text { Expected } \\
\text { (bp) }\end{array}$ \\
\hline \multirow{2}{*}{ Set 1} & GHTILAPIA-F0 & CAGAACCACCGACTCACATCATA & 60 & \multirow{2}{*}{764} \\
\hline & GHTILAPIA-R1 & TTGTTGAGCTGACGTTGCTCCT & 62 & \\
\hline \multirow{2}{*}{ Set 2} & GHTILAPIA-F1 & AGGAGCAACGTCAGCTCAACAA & 62 & \multirow{2}{*}{460} \\
\hline & GHTILAPIA-R2 & TTCTCTGCTTCATCCTGATTGGC & 60 & \\
\hline \multirow{2}{*}{ Set 3} & GHTILAPIA-F2 & GCCAATCAGGATGAAGCAGAGAA & 60 & \multirow{2}{*}{498} \\
\hline & GHTILAPIA-R0 & AGACTCCACACATCAATGCAACAC & 61 & \\
\hline
\end{tabular}

PCR reaction for each amplified region was prepared in a $50 \mu \mathrm{l}$ of $2 \mathrm{x}$ MyTaq Master Mix (Bioline, UK). PCR program was initiated with adenaturation step at $95{ }^{\circ} \mathrm{C}$ for $5 \mathrm{~min}$, followed by 35 cycles including $94^{\circ} \mathrm{C}$ for $45 \mathrm{sec}, 60^{\circ} \mathrm{C}$ for 1 min and $72^{\circ} \mathrm{C}$ for $1 \mathrm{~min}$, with a final extension at $72^{\circ} \mathrm{C}$ for 5 min. To test the PCR success, its product were loaded on a $1.5 \%$ agarose gel containing a $1 \mu$ of ethidium bromide (EthBr) using tris boric EDTA buffer (TBE) as a running buffer (Peacock, \& Dingman 1968). Successful PCR products (three fragments /species) were cleaned and concentrated using Gene JET PCR Purification Kit as \#K0701. Then cleaned fragments were sequenced by sequencing service (Macrogen, Netherlands). The obtained sequences of GH gene of the three tilapia species 
were deposited in the GenBank with the accession numbers; KT387598 for $O$. niloticus, KT387599 for S. galilaeus and KT387600 for T. zillii. http://www.ncbi.nlm.nih.gov/genbank/

\section{Data analysis}

Trace files of three tilapias species were obtained from the fragment analysis service and sorted according to sample order. All trace files were imported on inserted into the GENEIOUS program (V8.1) to automatically analyze the generated peaks and generate in the following sequence. Firstly, the three primers were designed for the $\mathrm{GH}$ gene, each one of them consist of forward and reverse sequences, which were collected pairwise alignment and the three fragments were collected from each primer. Secondly, a multiple alignment among them and BLAST search were done. After that, the sequence of the O. niloticus GH gene (M84774.1) from the Gene Bank was added as a reference for the three studied species. Then, the three studied species sequences were aligned with the reference sequence. Tow phylogenetic trees were made based on $\mathrm{GH}$ and their amino acids sequence. By using GENEIOUS program (V8.1) software. Introns, exons, annotations and nucleotide polymorphisms were specified. Comparison between the studied species with the similar species in the reference of GenBank by using MEGA6 program the phylogenetic trees were constructed, and generated using neighbor joining (NJ) method and confirmed by both maximum likelihood (ML) and minimum evolution (ME) methods, while the trees were tested using boot strap test of phylogeny method (many times).

\section{RESULTS AND DISCUSSION}

Growth hormone $(\mathrm{GH})$ gene has a vital role in controlling the growth performance in all organisms (Gross \& Nilsson, 1995; Gross et al., 1996). The evidence suggests that $\mathrm{GH}$ is the ancestral hormone in the molecular evolution of the GH/PRL/SL family and that the endocrine mechanism for growth stimulation was established at an early stage in the evolution of vertebrates (Moriyama et al., 2006). Therefore, a comparative analysis study of the GH gene among the studied tilapias species (Oreochromis niloticus, Sarotherodon galilaeus and Tilapia zillii) would help to find the explanation for the differences in the adult fish size and weight of T. zillii compared to its relative's O. niloticus and S. galilaeus (Van Oijen, 1995). For that reason, in the current study the growth hormone gene was isolated and analyzed (structure, features, transcription regulation...etc.) from the three tilapias species abundant in the Egyptian environment.

\section{GH gene sequences}

\section{Gene length polymorphism}

The structure of $\mathrm{GH}$ gene in the three tilapias species was studied. The gene lengths were variable among the three studied species which ranged from 1,572 $\mathrm{bp}$ to $1,601 \mathrm{bp}$. It was found that the $\mathrm{GH}$ gene is composed of six exons and five introns (Ber \& Daniel, 1992). All these exons were in the same length among the studied species. A comparison among the species intron lengths indicated that the first intron is the shortest one $(84-96 \mathrm{bp})$, while the second intron is the longest one $(403-436 \mathrm{bp})$. It was observed that all introns started with a GT dinucleotide and ended with an $\mathrm{AG}$ dinucleotide in accordance with the universal role $(\mathrm{Wu}, \&$ Krainer, 1999). As a result of the differences in intron lengths, the lengths of GH gene were differed among the studied species. Alignment of the three sequenced gene species showed a total length of $1,654 \mathrm{bp}$ in which 1,572 were identical 
(88.1\%), while the pairwise identity was 93.5\%. Nile tilapia (O. niloticus) showed an exact match to the reference sequence (Ber \& Daniel 1992) and showed the longest sequence which was $1,601 \mathrm{bp}$, followed by $T$. zillii and $S$. galilaeus which were 1,592 and 1,572 bp, respectively (Table 2).

Table 2: The start and end regions (bp) of each exon and intron among the three studied tilapias.

\begin{tabular}{cccc} 
Features & $\begin{array}{c}\text { O. niloticus } \\
\text { (KT387598) }\end{array}$ & $\begin{array}{c}\text { S. galilaeus } \\
\text { (KT387599) }\end{array}$ & $\begin{array}{c}\text { T. zillii } \\
\text { (KT387600) }\end{array}$ \\
\hline 5' Partial Exon1 & $1-10(10)$ & $1-10(10)$ & $1-10(10)$ \\
\hline Intron1 & $11-106(96)$ & $11-94(84)$ & $11-102(92)$ \\
\hline Exon2 & $107-240(134)$ & $95-228(134)$ & $103-236(134)$ \\
\hline Intron2 & $241-660(420)$ & $229-631(403)$ & $237-672(436)$ \\
\hline Exon3 & $661-777(117)$ & $632-748(117)$ & $673-789(117)$ \\
\hline Intron3 & $778-900(123)$ & $749-871(123)$ & $790-891(102)$ \\
\hline Exon4 & $901-1,044(144)$ & $872-1,015(144)$ & $892-1,035(144)$ \\
\hline Intron4 & $1,045-1,116(72)$ & $1,016-1,087(72)$ & $1,036-1,107(72)$ \\
\hline Exon5 & $1,117-1,263(147)$ & $1,088-1,234(147)$ & $1,108-1,254(147)$ \\
\hline Intron5 & $1,264-1,342(79)$ & $1,235-1,313(79)$ & $1,255-1,333(79)$ \\
\hline Exon6 & $1,343-1,601(259)$ & $1,314-1,572(259)$ & $1,334-1,592(259)$ \\
\hline
\end{tabular}

\section{Insertions and Deletions (Indels)}

Concerning the insertions and the deletions (Indels) recording, 56 indel code

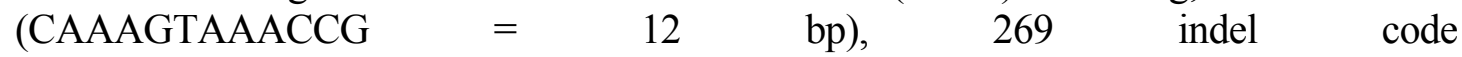
(TCAGACAGACAAGAGCTGACCAACAC-CTTCA $=31 \mathrm{bp}$ ) and 609 indel code $($ CTAACACTGG $=10 \mathrm{bp}$ ) were found to be unique in $T$. zillii. While 101 indel code $($ TGTC $=4 \mathrm{bp}$ ), 618 indel code (TGTTACCA $=8 \mathrm{bp}$ ) and 887 indel code (GTACCAGAGGTACTCTGCCCA $=21 \mathrm{bp}$ ) were found in both of O. niloticus and $S$. galilaeus but were deleted from T. zillii. 105 Indel code (TGTCTGTCTGTC $=12 \mathrm{bp}$ ) and 689 indel code (TTCTTTAATTCTACACA $=17 \mathrm{bp}$ ) were only found in O. niloticus and absent from the other two species (Table 3).

Table 3: Codes, start nucleotide number (min), end nucleotide number (max), length (bp), sequence and presence among the studied species for the GH gene.

\begin{tabular}{|c|c|c|c|c|c|c|c|}
\hline$\frac{\bar{E}}{\bar{\Xi}}$ & 疋 & 胥 & 폼 & 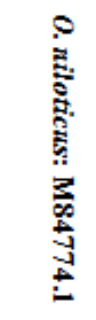 & 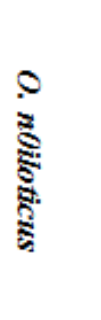 & 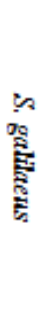 & 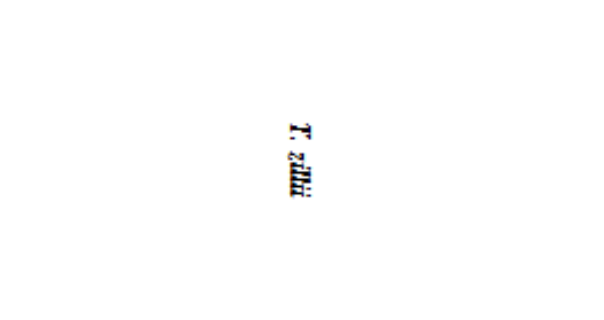 \\
\hline 56 & 56 & 67 & 12 & - & - & - & CAAAGTAAACCG \\
\hline 101 & 101 & 104 & 4 & \multicolumn{3}{|c|}{ TGTC } & - \\
\hline 105 & 105 & 116 & 12 & \multicolumn{2}{|c|}{ TGTCTGTCTGTC } & - & $-\quad-$ \\
\hline 269 & 269 & 299 & 31 & - & - & - & TCAGACAGACAAGAGCTGACCAACACCTTCA \\
\hline 609 & 609 & 619 & 10 & - & - & - & CTAACACTGG \\
\hline 618 & 618 & 688 & 8 & \multicolumn{3}{|c|}{ TGTTACCA } & - \\
\hline 689 & 689 & 705 & 17 & \multicolumn{2}{|c|}{ TTCTTTAATTCTACACA } & - & $-\quad-$ \\
\hline 887 & 887 & 907 & 21 & \multicolumn{3}{|c|}{ GTACCAGAGGTACTCTGCCCA } & - \\
\hline
\end{tabular}




\section{Substitutions}

It was observed that, O. niloticus reference (M84774.1), O. niloticus and S. galilaeus sequences were identical, with one exception to $S$. galilaeus which was a single difference at 383 site where the reference sequence was AC which substituted with $(>)$ AT sequence. While, T. zillii was totally different from the other species in nine substitutions (383AC $>$ GT, 490AGA $>$ GAG, 802TC $>$ CT, 912AT $>$ CA, 1086CT $>$ AA, $1133 \mathrm{TG}>\mathrm{CT}, 1162 \mathrm{CT}>\mathrm{GA}, 1165 \mathrm{TA}>\mathrm{GG}$ and 1168AG $>$ GT) (Table 4).

Table 4: Alignment codes, frequencies and ungapped base positions of these substitutions in the three different tilapias species.

\begin{tabular}{|c|c|c|c|c|c|c|c|}
\hline 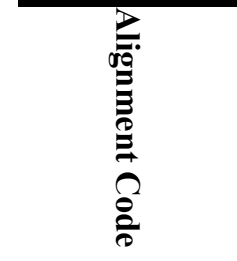 & 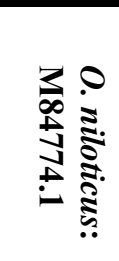 & 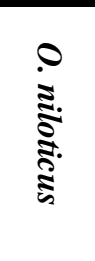 & 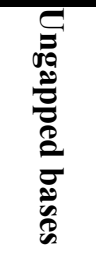 &  & 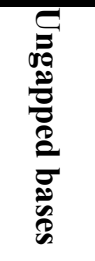 & $\begin{array}{l}- \\
\text { 站: }\end{array}$ &  \\
\hline $383 \mathrm{AC}>\mathrm{GT}$ & $\mathrm{AC}$ & $\mathrm{AC}$ & 340 & $\mathrm{AT}$ & 328 & GT & 367 \\
\hline $490 \mathrm{AGA}>\mathrm{GAG}$ & AGA & AGA & 447 & AGA & 435 & GAG & 474 \\
\hline$\overline{802 \mathrm{TC}>\mathrm{CT}}$ & $\mathrm{TC}$ & $\mathrm{TC}$ & 749 & $\mathrm{TC}$ & 720 & CT & 761 \\
\hline$\overline{912 \mathrm{AT}>\mathrm{CA}}$ & $\mathrm{AT}$ & $\mathrm{AT}$ & 859 & $\overline{\mathrm{AT}}$ & 830 & $\mathrm{CA}$ & 850 \\
\hline$\overline{1086 \mathrm{CT}>\mathrm{AA}}$ & $\mathrm{CT}$ & $\mathrm{CT}$ & 1033 & $\mathrm{CT}$ & 1004 & $\mathrm{AA}$ & 1024 \\
\hline $1133 \mathrm{TG}>\mathrm{CT}$ & $\mathrm{TG}$ & $\mathrm{TG}$ & 1079 & TG & 1050 & $\mathrm{CT}$ & 1070 \\
\hline $1162 \mathrm{CT}>\mathrm{GA}$ & $\mathrm{CT}$ & $\mathrm{CT}$ & 1109 & $\mathrm{CT}$ & 1080 & GA & 1100 \\
\hline $1165 \mathrm{TA}>\mathrm{GG}$ & $\mathrm{TA}$ & $\mathrm{TA}$ & 1112 & $\overline{\mathrm{TA}}$ & 1083 & $\mathrm{GG}$ & 1103 \\
\hline $1168 \mathrm{AG}>\mathrm{GT}$ & $\mathrm{AG}$ & $\mathrm{AG}$ & 1115 & $\overline{A G}$ & 1086 & GT & 1106 \\
\hline
\end{tabular}

\section{Nucleotide polymorphisms}

Exon sequences showed 26 nucleotide polymorphisms (NPs). The first partial exon sequence was totally conserved among the compared species. The sixth exon sequence had the highest number (12) of nucleotide polymorphism (NPs). Nucleotide substitutions were seen in the form of 20 transitions (A-G; T-C) and six trans-versions (G-C; G-T) in the exon sequence of the GH gene.

The total number of NPs in the intron sequences were 37. In comparison, the second intron sequence had the highest number (22) of NPs. While only one of NP was in the third intron sequence. Most of these NPs were found in T. zillii species. Nucleotide substitutions were seen in the form of 20 transitions (A-G; T-C) and 17 trans-versions (T-A; G-C; G-T) in the intron sequences. The sequences, nucleotides polymorphism (NPs), substitutions, insertions and deletions (Indels) are shown in (Figs. 1, 2 and 3). 


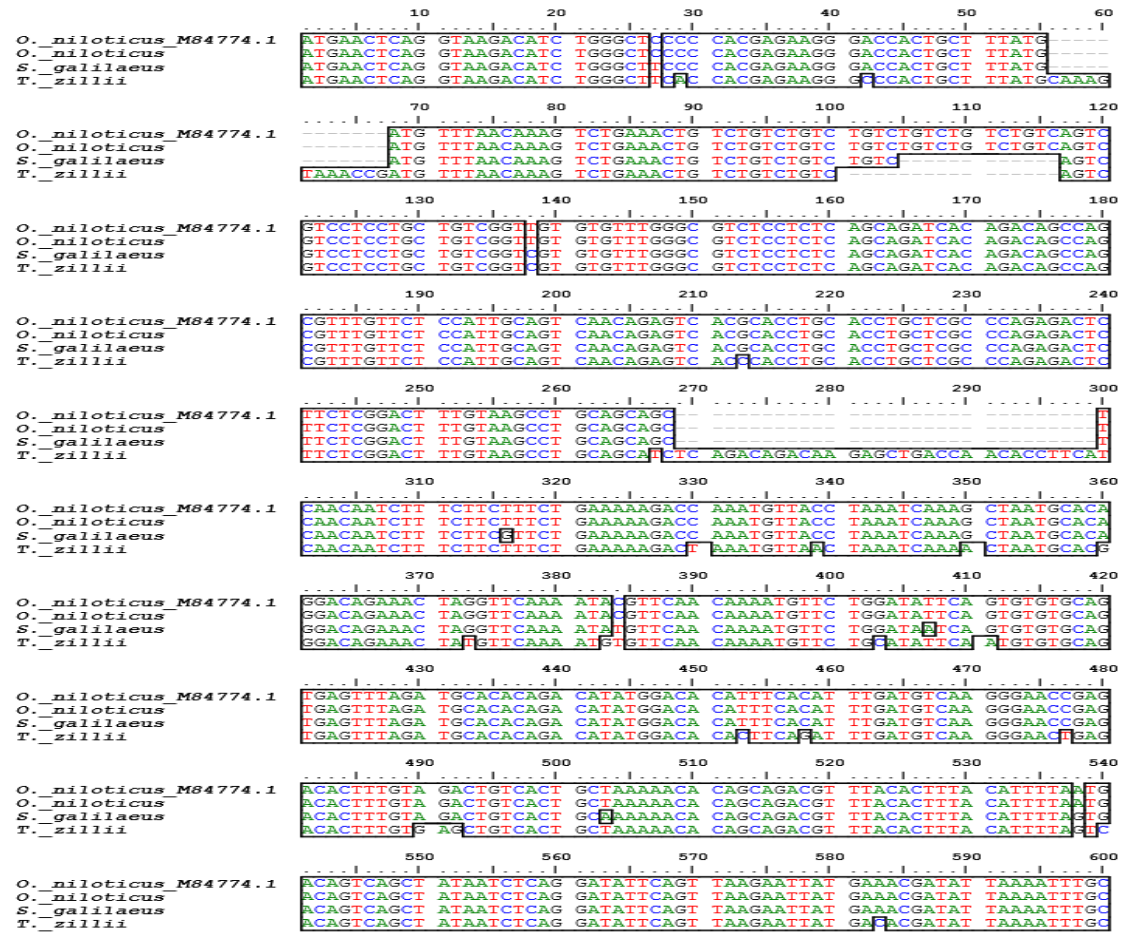

Fig. 1: Comparative of nucleotide alignment for $\mathrm{GH}$ gene sequence among tilapias species assembled to the reference sequence of O. niloticus (GenBank: M84774.1). Indels are the insertion/deletion sites (gaps) which written as (-) in the nucleotide alignment from $1 \mathrm{pb}$ to $600 \mathrm{pb}$.

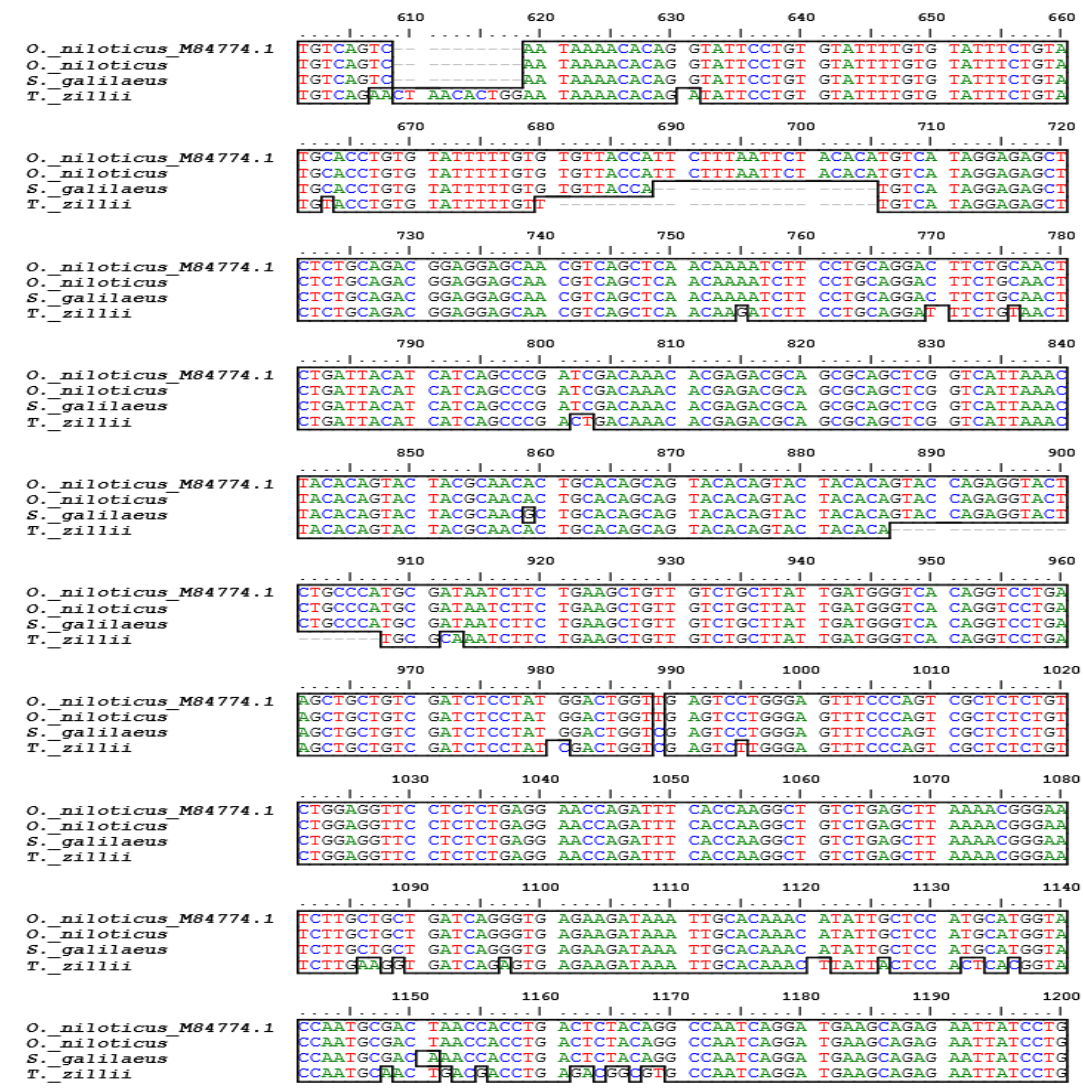

Fig. 2: Comparative of nucleotide alignment for $\mathrm{GH}$ gene sequence among tilapias species assembled to the reference sequence of O. niloticus (GenBank: M84774.1). Indels are the insertion/deletion sites (gaps) which written as (-) in the nucleotide alignment from $601 \mathrm{pb}$ to $1200 \mathrm{pb}$. 


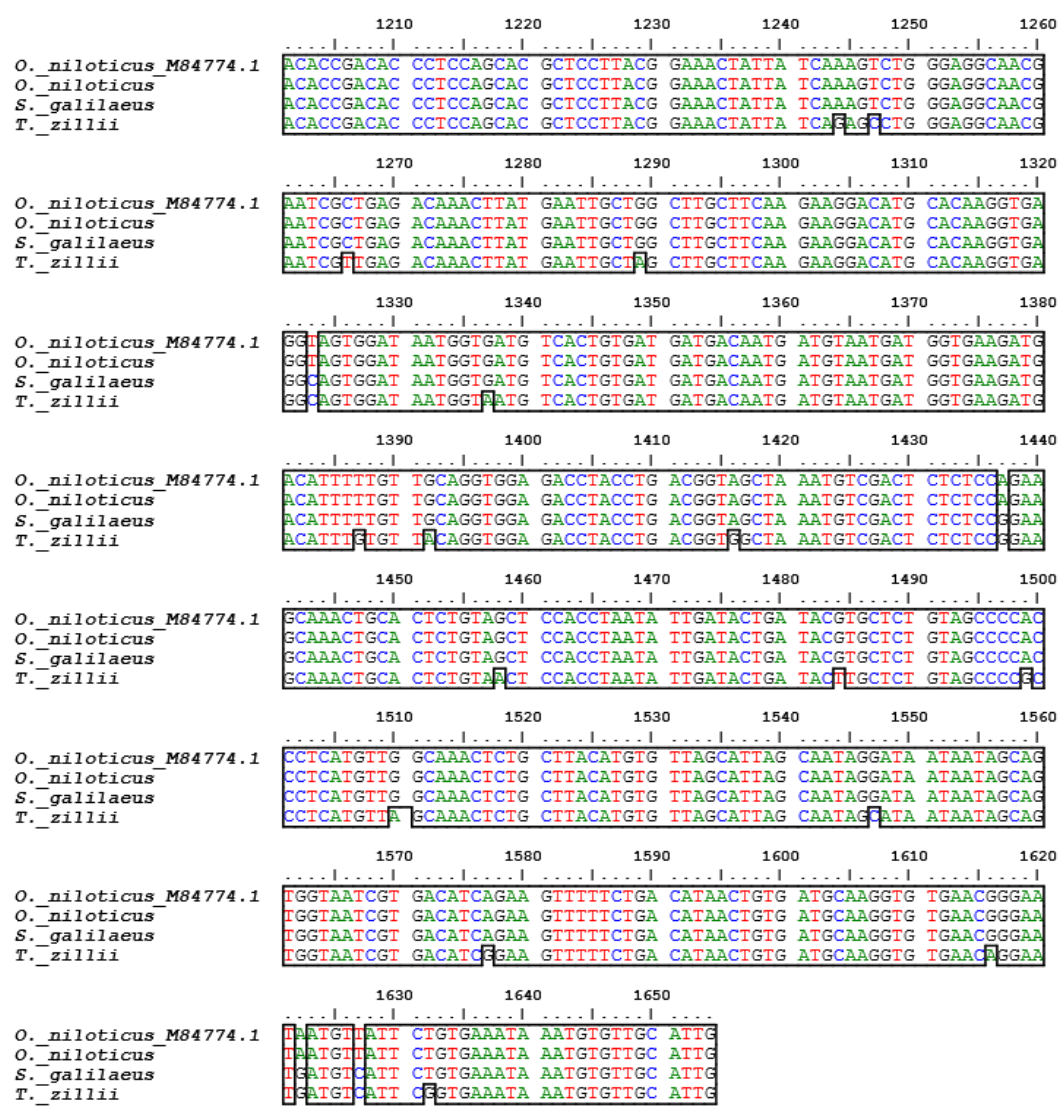

Fig. 3: Comparative of nucleotide alignment for GH gene sequence among tilapias species assembled to the reference sequence of $O$. niloticus (GenBank: M84774.1). Indels are the insertion/deletion sites (gaps) which written as (-) in the nucleotide alignment from $1201 \mathrm{pb}$ to $1654 \mathrm{pb}$.

\section{Amino acid polymorphisms}

The length of individual exon was the same in all the tilapias species with an open reading frame (ORF) of 615 bp (204 amino acids codons +1 stop codon). The sequence started by the start codon of Methionine (M) according to the standard translation table and ended by the codon of Leucine (L). The most frequent amino acid was Leucine (91 time, 14.9\%), followed by Serine (78 time, 12.7\%), while the least frequent was Tryptophan (3 times, 0.5\%) (Table 5).

The GH amino acid sequences of tilapias species exhibited homology in all amino acids expect four amino acids which were different [Isoleucine (I) $>$ Threonine (T), Glycine $(\mathrm{G})>$ Arginine $(\mathrm{R})$, Leucine $(\mathrm{L})>$ Lysine $(\mathrm{K})$ and Leucine (L)> Valine (V)] in 78, 97, 132 and 133 sites, only of in T. zillii (Table 6). 
Table 5: Amino acids frequency of GH gene from tilapiine species. The lowest and highest amino acids are written in bold.

\begin{tabular}{cccc}
\hline Amino acid & Abbreviation & Frequency & Percentage $\%$ \\
\hline Tryptophan & Trp (W) & $\mathbf{3}$ & $\mathbf{0 . 5}$ \\
\hline Methionine & Met (M) & 6 & 1.0 \\
\hline Cysteine & Cys (C) & 15 & 2.5 \\
\hline Histidine & His (H) & 15 & 2.5 \\
\hline Proline & Pro (P) & 18 & 2.9 \\
\hline Phenylalanine & Phe (F) & 21 & 3.4 \\
\hline Glycine & Gly (G) & 23 & 3.8 \\
\hline Alanine & Ala (A) & 24 & 3.9 \\
\hline Tyrosine & Tyr (Y) & 24 & 3.5 \\
\hline Lysine & Lys (K) & 25 & 4.1 \\
\hline Aspartic Acid & Asp (D) & 27 & 4.4 \\
\hline Isoleucine & Ile (I) & 29 & 4.9 \\
\hline Asparagine & Asn (N) & 30 & 5.6 \\
\hline Arginine & Arg (R) & 34 & 5.6 \\
\hline Threonine & Thr (T) & 34 & 5.6 \\
\hline Valine & Val (V) & 6.4 \\
\hline Glutamic Acid & Glu (E) & 34 & 6.9 \\
\hline Glutamine & Gln (Q) & 39 & 12.7 \\
\hline Serine & Ser (S) & 42 & $\mathbf{1 4 . 9}$
\end{tabular}

Table 6: Differences in amino acids of GH gene sequences among tilapias species.

\begin{tabular}{|c|c|c|c|}
\hline Amino Acid site & O. niloticus & S. galilaeus & T. zillii \\
\hline aa78 & Isoleucine (I) & Isoleucine (I) & Threonine $(\mathrm{T})$ \\
\hline aa97 & Glycine $(\mathrm{G})$ & Glycine $(\mathrm{G})$ & Arginine (R) \\
\hline aa132 & Leucine (L) & Leucine (L) & Lysine $(\mathrm{K})$ \\
\hline aa133 & Leucine (L) & Leucine (L) & Valine (V) \\
\hline
\end{tabular}

Majority of the detected mutations were located in intron sequences, which ultimately led to divergence in the length of the GH gene. Additionally, T. zillii species showed high variation in four amino acid sites against none between $O$. niloticus and S. galilaeus species. Based on this fact, this discrepancy might be the logical explanation for the growth delay in T. zillii species.

Phylogenetic and evolutionary relationship

By using MEGA6 program the phylogenetic trees for GH gen sequences were made and were generated using neighbor joining (NJ) and confirmed by both maximum likelihood (ML) method and minimum evolution (ME) methods for the three studied species along with approximate sequence obtained from GenBank database. Phylogenetic trees were performed based on both complete sequence (exons and introns) data and coding DNA sequence data (CDS: exons only).

\section{Complete sequence}

The evolutionary divergence among the three studied tilapias species based on the complete GH gene sequence was determined including the available GenBank accessions in which the complete $\mathrm{GH}$ gene is recorded. The largest genetic divergence was detected between T. zillii species and O. mossambicus Y11732 accession (0.57), followed by the divergence between $T$. zillii and $O$. niloticus species $(0.51)$. While the smallest genetic divergence was detected between O. niloticus M97766 accession and 
O. mossambicus Y11732 accession as well as between $O$. niloticus species and $O$. mossambicus Y11732 accession (0.08), followed by S. galilaeus and O. niloticus species (0.09) (Table 7).

Table 7: Estimates of evolutionary divergence among the three studied tilapias species based on complete GH gene sequence.

\begin{tabular}{|c|c|c|c|c|c|}
\hline Species & O. niloticu & s S. galilaeus & $S$ T. zillii & $\begin{array}{l}\text { O. niloticus } \\
\text { (M97766) }\end{array}$ & $\begin{array}{c}\text { O. mossambicus } \\
(\text { Y11732) }\end{array}$ \\
\hline O. niloticus & 0.00 & & & & \\
\hline S. galilaeus & 0.09 & 0.00 & & & \\
\hline T. zillii & 0.51 & 0.49 & 0.00 & & \\
\hline O. niloticus (M97766) & 0.00 & 0.09 & 0.51 & 0.00 & \\
\hline O. mossambicus (Y11732) & 0.08 & 0.14 & 0.57 & 0.08 & 0.00 \\
\hline
\end{tabular}

The phylogenetic tree based on the complete $\mathrm{GH}$ gene sequence was generated as shown in (Fig. 2). The tree shared one main cluster with a single outlier. The main cluster included O. niloticus species and O. niloticus (GenBank: M97766 accession) together which the bootstrap values of NJ, ML and ME method were 89, 88 and 86, respectively. O. mossambicus (GenBank: Y11732 accession) was located together with $O$. niloticus species in the same cluster, which the bootstrap values of NJ and ML methods were 100 and 99 respectively, while $S$. galilaeus species was paraphyletic (sub clade). On the other hand, the only single outlier was $T$. zillii species.



Fig. 2: Phylogenetic relationship tree of the three studied tilapias species based on the complete GH gene.

\section{Complete CDS}

The evolutionary divergence among the three studied tilapias species based on the complete CDS was determined including the available GenBank accessions in which the complete coding DNA sequence is recorded. The largest genetic divergence was detected between $T$. zillii species and O. mossambicus Y11732 accession (0.49), followed by the divergence between T. zillii species and O. urolepis EF371465 accession (0.44). While the smallest genetic divergence was detected between $O$. niloticus and $S$. galilaeus species as well as between $S$. galilaeus species and $O$. niloticus (M26916) accession (0.05), followed by $O$. niloticus species and O. urolepis EF371465 accession (0.12) (Table 8). 
Table 8: Estimates of evolutionary divergence among the three studied tilapias species based on complete CDS.

\begin{tabular}{|c|c|c|c|c|c|c|}
\hline 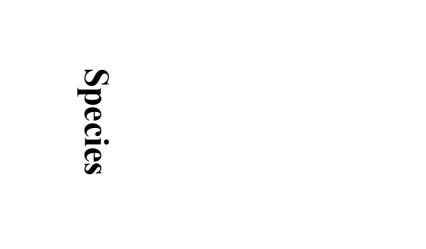 &  & 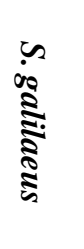 & $\stackrel{-}{\stackrel{-}{*}}$ & 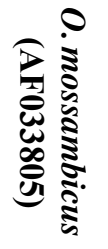 & 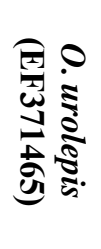 & 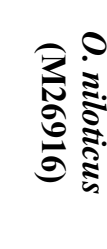 \\
\hline O. niloticus & 0.00 & & & & & \\
\hline S. galilaeus & 0.05 & 0.00 & & & & \\
\hline T. zillii & 0.35 & 0.30 & 0.00 & & & \\
\hline O. mossambicus (AF033805) & 0.13 & 0.18 & 0.49 & 0.00 & & \\
\hline O. urolepis (EF371465) & 0.12 & 0.13 & 0.44 & 0.18 & 0.00 & \\
\hline O. niloticus (M26916) & 0.00 & 0.05 & 0.35 & 0.13 & 0.12 & 0.00 \\
\hline
\end{tabular}

The phylogenetic tree based on complete CDS was generated as shown in (Fig. 3). The tree was divided into two main clusters with a single outlier. The first cluster included O. niloticus species and O. niloticus (GenBank: M97766) accession together, which the bootstrap values of NJ, ML and ME methods were 57, 56 and 55, respectively. Oreochromis mossambicus (GenBank: AF033805) accession and O. urolepis (GenBank: EF371465) accession were located together with $O$. niloticus species in the same cluster, which the bootstrap values of NJ, ML and ME methods were 80, 75 and 69, respectively. While the second cluster included $S$. galilaeus and T. zillii species which the bootstrap values of NJ, ML and ME methods were 97, 96 and 90, respectively. On the other hand, T. zillii species was the only single outlier.

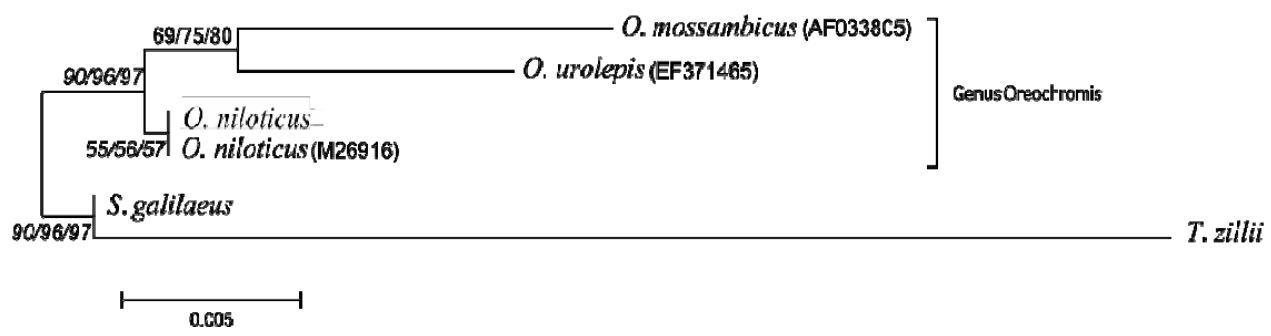

Fig. 3: Phylogenetic relationship tree of the three studied tilapias species based on the complete CDS.

Tilapia zillii taxonomically belongs to the genus Tilapia, while O. niloticus belong to genus Oreochromis and S. galilaeus belongs to genus Sarotherodon. Even though each of the three studied tilapias belongs to different genus, it appeared from our results that $T$. zillii species is far more distant to $O$. niloticus species than to $S$. galilaeus species. Schwarzer et al., (2009) constructed a phylogenetic tree for cichlid fishes in East African Cichlid using multi-locus DNA analysis and four mitochondrial genes. The phylogenetic tree separated the so called "Tilapia" in a paraphyletic assemblage, and established three new monophyletic groups; "Oreochromini", "Boreotilapiini" and "Austrotilapiini" they supported the high genetic distance between $T$. zillii species and the other studied fish species.

In conclusion, by studying the GH gene structure, T. zillii species was found to be clearly different from the other studied fish species (gene length, interspecies nucleotide polymorphism and variation in amino acid composition). Such assumption, 
moreover, was supported by the phylogenetic analysis based on the complete GH gene sequence, which showed a clear genetic divergence between $T$. zillii species and the other studied species.

\section{REFERENCES}

Agellon, L., Davies, S., Chen, T. and Powers, D (1988). Structure of a fish (rainbow trout) growth hormone gene and its evolutionary implications. Proceedings of the National Academy of Sciences, 85: 5136-40.

Ber, R. and Daniel, V (1992). Structure and sequence of the growth hormoneencoding gene from Tilapia nilotica. Gene, 113: 245-50.

Bwanika, G., Makanga, B., Kizito, Y., Chapman, L., and Balirwa, J. (2004). Observations on the biology of Nile tilapia, Oreochromis niloticus L., in two Ugandan crater lakes. African Journal of Ecology, 42(s1): 93-101.

Dänicke, S. (2006). Hormonal regulation of farm animal growth, K.L. Hossner (Ed.). CABI Publishing (2005). Animal Feed Science and Technology, 128: 173-174.

Food and Agriculture Organisation (FAO), (2002). Global Agro-ecological Assessment for Agriculture in the 21st Century: Methodology and Results, Food and Agriculture Organisation, Rome, Italy.

Glass, D. J. (2003). Molecular mechanisms modulating muscle mass. Trends in molecular medicine, 9:344-50.

Glass, D. J. (2005). Skeletal muscle hypertrophy and atrophy signaling pathways. The international journal of biochemistry and cell biology, 37:1974-84.

Gross, R. and Nilsson, J (1995). Application of heteroduplex analysis for detecting variation within the growth hormone 2 gene in brown trout. (Salmo trutta). Heredity (Edinb), 74(3):286-95.

Gross, R., Stein, H. and Rottmann, O (1996). Detection of allelic variation within the growth hormone gene in common bream using heteroduplex analysis. Journal of fish biology, 48:1283-87.

Kapetsky, J. M. and Petr, T (1984). Status of African reservoir fisheries. FAO.

Lopera-Barrero, N. M., Povh, J. A., Ribeiro, R. P., Gomes, P. C., Jacometo, C. B. and Silva Lopes, T. D (2008). Comparación de protocolos de extracción de ADN con muestras de aleta y larva de peces: extracción modificada con cloruro de sodio. Ciencia e investigación agraria, 35:77-86.

Ma, X., Liu, X., Zhang, Y., Zhu, P., Ye, W. and Lin, H. (2007). Two growth hormone receptors in Nile tilapia (Oreochromis niloticus): Molecular characterization, tissue distribution and expression profiles in the gonad during the reproductive cycle. Comparative Biochemistry and Physiology Part B: Biochemistry and Molecular Biology, 147(2):325-339.

Moriyama, S., Oda, M., Takahashi, A., Sower, S. A. and Kawauchi, H. (2006). Genomic structure of the sea lamprey growth hormone-encoding gene. General and comparative endocrinology, 148:33-40.

Peacock, A. C. and Dingman, C. W (1968). Molecular weight estimation and separation of ribonucleic acid by electrophoresis in agarose-acrylamide composite gels. Biochemistry, 7:668-74.

Pendón, C., Martínez-Barberá, J. P., Pérez-Sánchez, J., Rodríguez, R. B., Grenett, H. and Valdivia, M. M (1994). Cloning of the sole (Solea senegalensis) growth hormone-encoding cDNA. Gene, 145: 237-40.

Reinecke, M., Björnsson, B. T., Dickhoff, W. W., Mccormick, S. D., Navarro, I., Power,D. M. and Gutiérrez, J (2005). Growth hormone and insulin-like growth 
factors in fish: where we are and where to go. General and comparative endocrinology, 142:20-24.

Schwarzer, J., Misof, B., Tautz, D. and Schliewen, U. K (2009). The root of the East African cichlid radiations. BMC Evolutionary Biology, 9: 186.

Stiassny, M. L., Teugels, G. G. and Hopkins, C. D (2007). Fresh and Brackish Water Fishes of Lower Guinea, West-Central Africa, IRD Editions.

Van Oijen, M. (1995). Key to Lake Victoria fishes other than haplochromine cichlids. Fish stocks and fisheries of Lake Victoria: A handbook for field observations. Samara Publishing Limited, Dyfed, Great Britain, pp. 209-300.

Velloso, C. (2008). Regulation of muscle mass by growth hormone and IGF-I. British journal of pharmacology, 154:557-68.

Wood, A. W., Duan, C., and Bern, H. A. (2005). Insulin-like growth factor signaling in fish. International review of cytology, 243: 215-285.

Wu, Q., \& Krainer, A. R. (1999). AT-AC pre-mRNA splicing mechanisms and conservation of minor introns in voltage-gated ion channel genes. Molecular and cellular biology, 19(5):3225-3236.

Yowe, D. L. and Epping, R. J (1995). Cloning of the barramundi growth hormone- encoding gene: a comparative analysis of higher and lower vertebrate GH genes. Gene, 162:255-59.

\section{ARABIC SUMMARY}

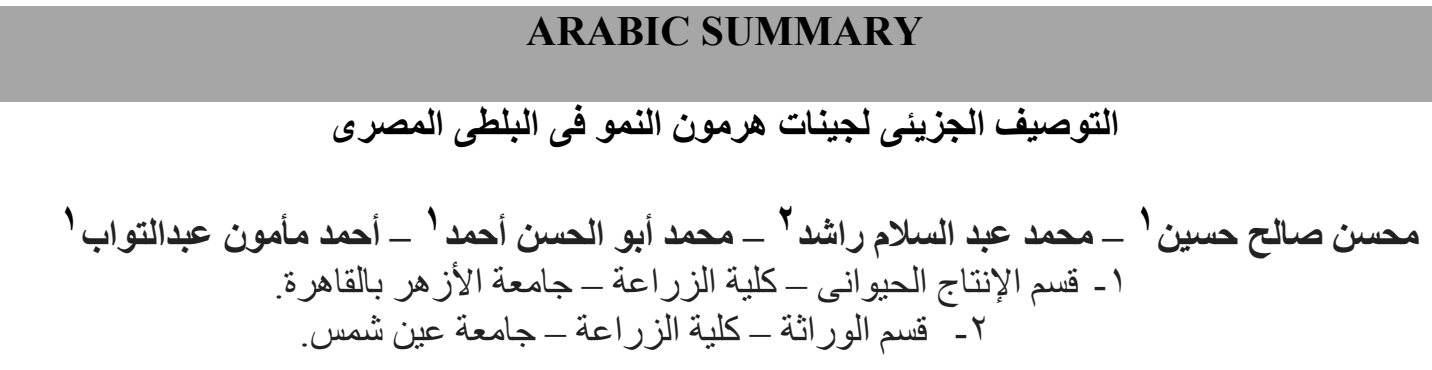

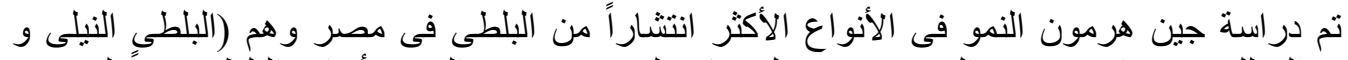

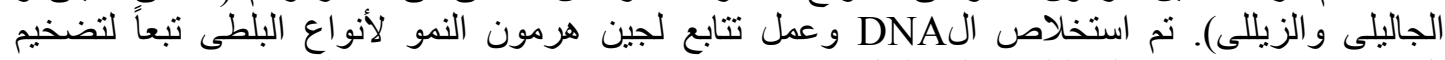

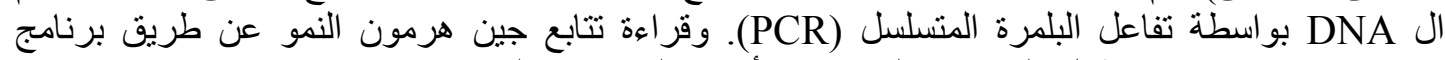
GENEIOUS

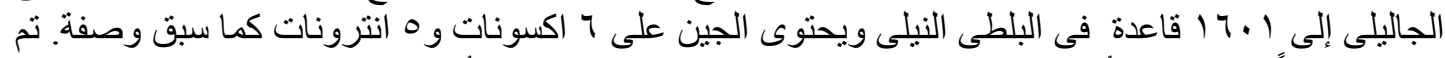

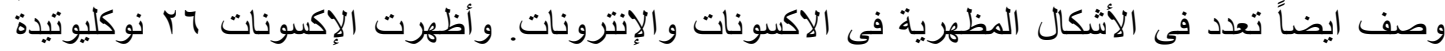

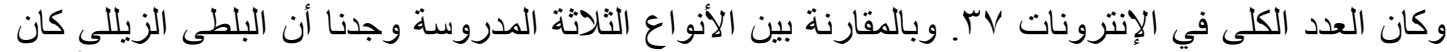



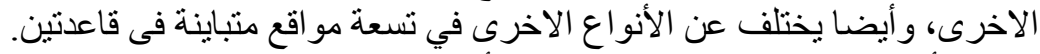





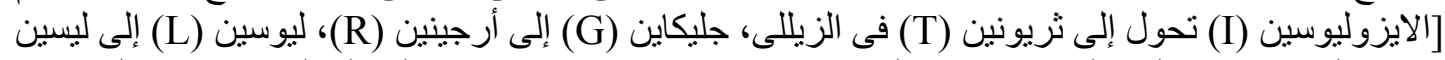

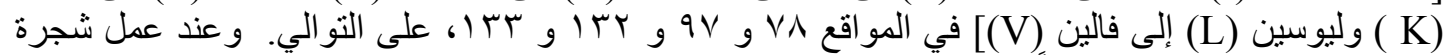
القر ابة كان البلطى الزيللى بعيداً عن الأنواع الاخرى. 